\title{
Biological functions of UDP-glucose synthesis in Streptococcus mutans
}

\author{
Yoshihisa Yamashita, Yuichi Tsukioka, Yoshio Nakano, \\ Kiyotaka Tomihisa, Takahiko Oho and Toshihiko Koga
}

Department of Preventive Dentistry, Kyushu University Faculty of Dentistry, 3-1-1 Maidashi Higashi-ku, Fukuoka 8128582, Japan
Author for correspondence: Toshihiko Koga. Tel: +8192642 6350. Fax: +81926426354. e-mail: toshidha@mbox.nc.kyushu-u.ac.jp
Keywords: Streptococcus mutans, UDP-glucose, glucose-1-phosphate uridylyltransferase, polysaccharide antigen, acid tolerance

\section{INTRODUCTION}

Serotype-specific polysaccharide antigens of Streptococcus mutans are composed of a backbone structure of 1,2- and 1,3-linked rhamnosyl polymers with glucose side-chains (Wetherell \& Bleiweis, 1975; Linzer et al., 1986; Pritchard et al., 1986) and their serological detection has been used extensively in classification of cariogenic streptococci (Loesche et al., 1986). These polysaccharide antigens have received increasing attention because in vitro stimulation of human monocytes with the serotype-f-specific polysaccharide antigen of $S$. mutans was reported to induce the release of inflammatory cytokines such as tumour necrosis factor alpha and interleukin-1 (Soell et al., 1995), and shown to provoke nitric oxide production in the rat aorta (Martin et al., 1997). However, the biosynthetic pathway of these polysaccharide antigens has not been elucidated. We have recently cloned two loci related to the dTDP-L-rhamnose synthesis pathway and demonstrated that four genes $(r m l A, r m l B, r m l C$ and $r m l D)$ are involved in dTDP-L-rhamnose synthesis from glucose 1-

The EMBLGenBank/DDBJ accession number for the 3313 bp nucleotide sequence described in this paper is $A B 001562$. phosphate in S. mutans (Tsukioka et al., 1997a, b). Rhamnose is not detected in cell-wall preparations from mutants in which any one of the four $\mathrm{rml}$ genes is insertionally inactivated. Furthermore, rabbit antiserum against $S$. mutans serotype-c-specific antigen does not react with autoclaved extracts from these mutants. These findings suggest that dTDP-rhamnose is used as an immediate precursor for the synthesis of the backbone of the serotype-c-specific antigen of $S$. mutans.

Glucose-1-phosphate uridylyltransferase (EC 2.7.7.9), which catalyses a reaction converting D-glucose 1phosphate and UTP to UDP-D-glucose, is widely distributed in animals, plants and micro-organisms. The UDP-D-glucose produced is then used as a glucosyl donor in the biosynthesis of various carbohydrates (Ginsburg, 1964; Markovitz, 1977; Schnaitman \& Klena, 1993; Sundararajan et al., 1962; Weissborn et al., 1994). It is possible that UDP-D-glucose is a nucleotide sugar used as a glucosyl donor for side-chain formation of the serotype-specific antigen in S. mutans. There is, however, no information concerning the mechanism of glucose side-chain formation of the antigen. Several reports have suggested that bacterial UDP-D-glucose synthesis is involved in osmotolerance and thermotolerance (Böhringer et al., 1995; Giæver et al., 1988; 
Hengge-Aronis et al., 1991). Acid tolerance of S. mutans plays a key role in demineralization of human dental enamel. We have previously shown that a mutation in the gene encoding a diacylglycerol kinase homologue leads not only to the loss of acid tolerance but also to the loss of osmotolerance and thermotolerance (Yamashita et al., 1993). Little is known, however, about the role that UDP-D-glucose synthesis may play in the organism's tolerance of environmental stresses.

In the present study, we cloned the gene from $S$. mutans which encodes a glucose-1-phosphate uridylyltransferase, and analysed the function of the protein encoded by this gene.

\section{METHODS}

Bacterial strains and culture conditions. S. mutans strains, Escherichia coli strains and plasmids used in this study are listed in Tables 1 and 2. Streptococcus pneumoniae WU2 was kindly provided by J. Yother, Department of Microbiology, University of Alabama at Birmingham, AL, USA. The other bacteria used in this study were obtained as previously described (Tsukioka et al., 1997a). Strains of S. mutans and E. coli were maintained and grown routinely as described previously (Yamashita et al., 1993). Antibiotics were used at the following concentrations: $150 \mathrm{mg}$ erythromycin $\mathrm{l}^{-1}$ or $50 \mathrm{mg}$ ampicillin $\mathrm{l}^{-1}$ for $E$. coli; $10 \mathrm{mg}$ erythromycin $\mathrm{l}^{-1}$ for $S$. mutans. Bacillus subtilis was grown aerobically in Luria-Bertani medium at $37^{\circ} \mathrm{C}$. Clostridium bifermentans was grown anaerobically in GAM broth (Nissui Medical, Tokyo, Japan) at $37^{\circ} \mathrm{C}$. S. pneumoniae was grown in Todd-Hewitt broth (Difco) supplemented with $1 \%(\mathrm{w} / \mathrm{v})$ yeast extract and $5 \%$ horse serum at $37{ }^{\circ} \mathrm{C}$ in a $5 \% \quad \mathrm{CO}_{2}$ atmosphere. Streptococcus species (except for S. pneumoniae), Entero- coccus faecalis and Eubacterium limosum were grown anaerobically in brain heart infusion broth (Difco) at $37^{\circ} \mathrm{C}$. Staphylococcus aureus, Micrococcus luteus, Lactobacillus case $i$ and Mycobacterium smegmatis were grown aerobically in brain heart infusion broth at $37^{\circ} \mathrm{C}$.

DNA manipulations and sequence analyses. Standard DNA recombinant procedures such as DNA isolation, endonuclease restriction and ligation were carried out as described by Sambrook et al. (1989). Transformation of S. mutans and E. coli was carried out as previously described (Yamashita $e t$ al., 1993). Chromosomal DNA of all the bacteria used in this study except for Mycobacterium smegmatis was prepared as described by Perry et al. (1983). Chromosomal DNA of Mycobacterium smegmatis was prepared by the method of Imai et al. (1994). The nucleotide sequence of the insert fragment was determined using a 373 STRETCH automated sequencer (Applied Biosystems) as described previously (Yamashita et al., 1993). The galU gene with the Tn5 insertion was transferred from $E$. coli strain JC7623-16 to E. coli strain S $\phi 874$ by P1 transduction (Miller, 1992). The nucleotide sequence was assembled using the DNASIS sequence analysis program (Hitachi Software Engineering). Database searching was performed using the FASTA program (Lipman \& Pearson, 1985 ) of the DDBJ electronic-mail server in the National Institute of Genetics, Mishima, Japan. Multiple alignments of the amino acid sequences were generated with the CLUSTAL $v$ program (Higgins et al., 1992).

Southern blot analysis and colony hybridization. Southern blot analysis and colony hybridization were performed with digoxigenin-labelled $P C R$ probes using a nonradioactive digoxigenin DNA labelling and detection kit (DIG-ELISA) (Boehringer Mannheim) according to the instructions of the supplier. To detect the $S$. mutans gene homologous to cps $3 U$ encoding a glucose-1-phosphate uridylyltransferase of $S$. pneumoniae WU2, a set of primers (5'-TACGTTCGGGTA-

Table 1. E. coli and S. mutans strains used

\begin{tabular}{|c|c|c|}
\hline Strain & Genotype or relevant characteristic & Reference \\
\hline \multicolumn{3}{|l|}{ E. coli } \\
\hline JM109 & $\begin{array}{l}\mathrm{F}^{-} \text {recA1 supE44 endA1 bsdR17 gyrA96 relA1 } \\
\text { thi } \Delta(\text { lac-pro } A B)\end{array}$ & Yanisch-Perron et al. (1985) \\
\hline S $\phi 874$ & $\begin{array}{l}\text { lacZ2286 trp-49 } \Delta(s b c B-r f b) 86 \text { upp-12 relA1 } \\
\quad r p s L 150 \lambda^{-}\end{array}$ & Jiang et al. (1991) \\
\hline JC7623-16 & recBrecCsbcD galU:: $\operatorname{Tn} 5-16$ & Weissborn et al. (1994) \\
\hline $\mathrm{S} \phi 874-16$ & As $\mathrm{S} \phi 874$ but with galU:: $\operatorname{Tn} 5-16$ & This study \\
\hline KD300 & S $\phi 874-16$ carrying pBluescriptII $\mathrm{KS}^{+}$ & This study \\
\hline KD301 & S $\phi 874-16$ carrying pMG1 & This study \\
\hline \multicolumn{3}{|l|}{ S. mutans } \\
\hline $\mathrm{Xc}$ & Serotype $c$ wild-type strain & Koga et al. (1989) \\
\hline $\mathrm{Xc22}$ & $\begin{array}{l}\mathrm{Em}^{\mathrm{r}} \text {; strain Xc carrying P15A replicon and } \\
\mathrm{Em}^{\mathrm{r}} \text { gene inserted into ORF3, immediately } \\
\text { upstream of } r \mathrm{mlA}\end{array}$ & Tsukioka et al. (1997a) \\
\hline $\mathrm{Xc24}$ & $\begin{array}{l}\mathrm{Em}^{\mathrm{r}} \text {; strain Xc carrying P15A replicon and } \\
\mathrm{Em}^{\mathrm{r}} \text { gene inserted into } \mathrm{rmlB}\end{array}$ & Tsukioka et al. (1997a) \\
\hline $\mathrm{Xc31}$ & $\begin{array}{l}\mathrm{Em}^{\mathrm{r}} \text {; strain Xc carrying P15A replicon and } \\
\mathrm{Em}^{\mathrm{r}} \text { gene inserted into gluA }\end{array}$ & This study \\
\hline MT8148 & Serotype c strain & Ohta et al. (1989) \\
\hline MT703 & Serotype e strain & Hamada \& Slade (1976) \\
\hline OMZ175 & Serotype f strain & Bratthall $(1970)$ \\
\hline
\end{tabular}


Table 2. Plasmids used

\begin{tabular}{|c|c|c|}
\hline Plasmid & Relevant characteristic & Source or reference \\
\hline pBluescriptII KS ${ }^{+}$ & $\mathrm{Ap}^{\mathrm{r}}$; phagemid cloning vector & Stratagene \\
\hline pYT6 & $\begin{array}{l}\text { pBluescriptII } \mathrm{KS}^{+} \text {containing } 3.3 \mathrm{~kb} \mathrm{XbaI} \\
\text { fragment of } \mathrm{Xc} \text { chromosomal DNA }\end{array}$ & This study (Fig. 1) \\
\hline pMG1 & pBluescriptII $\mathrm{KS}^{+}$containing $g l u A$ & This study (Fig. 1) \\
\hline pResEmNot & $\mathrm{Em}^{\mathrm{r}} ; \mathrm{P} 15 \mathrm{~A}$ replicon & Shiroza \& Kuramitsu (1993) \\
\hline pYT31 & $\begin{array}{l}\text { pMG1 containing pResEmNot ligated into } \\
\text { Hincll site of gluA }\end{array}$ & This study \\
\hline pJD366 & $\begin{array}{l}\text { pJY } 4164 \text { containing } 3.2 \mathrm{~kb} \text { HindIII fragment } \\
\text { of } S \text {. pneumoniae WU } 2 \text { chromosomal } \\
\text { DNA }\end{array}$ & Dillard \& Yother (1994) \\
\hline
\end{tabular}

TTGAAG- $3^{\prime}$ and $5^{\prime}$-AGGTGTCCACTTGACGAACA-3') and pJD366, which carries cps3U (Dillard \& Yother, 1994), were used for amplification of a $0.8 \mathrm{~kb}$ digoxigenin-labelled PCR probe (probe 1). Hybridization with probe 1 was carried out overnight at $25^{\circ} \mathrm{C}$ in the presence of $50 \%$ formamide. To confirm appropriate insertional inactivation of the $g l u A$ gene and to detect gluA-specific hybridization signals in the chromosomal DNA of various bacterial species, a set of primers ( $5^{\prime}$-AGCTGTCATCCCTGCGGC- ${ }^{\prime}$ and $5^{\prime}$-CCGAGTTCTTTTGAGTCG-3') was designed and a digoxigeninlabelled PCR probe (probe 2 ) was amplified using the primers and pMG1.

Insertional inactivation of the gluA gene. pResEmNot, containing an erythromycin resistance cassette (Shiroza \& Kuramitsu, 1993), was digested with NotI and blunt-ended with T4 DNA polymerase. The linearized $1.6 \mathrm{~kb}$ pResEmNot was ligated into the HincII site in the gluA gene of pMG1. The resultant plasmid, designated pYT31, was digested with $B s s \mathrm{HII}$ and the digested plasmid DNA was introduced into $S$. mutans Xc by homologous recombination. The transformants were screened on a mitis-salivarius agar plate containing $10 \mu \mathrm{g}$ erythromycin $\mathrm{ml}^{-1}$ and three independent transformants which appeared on the agar plate were isolated. The appropriate insertion of pResEmNot in the gluA gene was confirmed by Southern blot analysis of $\mathrm{XbaI}$ digests with probe 2 . Hybridization with probe 2 was carried out overnight at $42{ }^{\circ} \mathrm{C}$ in the presence of $50 \%$ formamide. The $\mathrm{XbaI}$ digested chromosomal DNA from all three transformants showed a $4.9 \mathrm{~kb}$ fragment which hybridized with probe 2 , while that of $\mathrm{Xc}$ hybridized to a $3.3 \mathrm{~kb}$ fragment (data not shown). One of these three transformants was designated $\mathrm{Xc31}$ and tested for further characterization. The phenotype of the other transformants was very similar to that of Xc31 (data not shown).

SDSPAGE. Expression of the gluA gene in E. coli $\mathrm{S} \phi 874-16$ was confirmed by SDS-PAGE (Laemmli, 1970). E. coli strain $\mathrm{KD} 301$ or $\mathrm{KD} 300$ was grown at $37^{\circ} \mathrm{C}$ in $5 \mathrm{ml}$ Luria-Bertani broth containing $50 \mathrm{mg}$ ampicillin $\mathrm{l}^{-1}$. Gene expression was induced with $0.3 \mathrm{mM}$ IPTG for $3 \mathrm{~h}$. The cells were harvested and suspended in SDS sample buffer containing $10 \mathrm{mM}$ Tris $/ \mathrm{HCl}(\mathrm{pH} 6.8), 1 \%(\mathrm{w} / \mathrm{v})$ SDS, $1 \%$ (v/v) mercaptoethanol and $20 \%(\mathrm{v} / \mathrm{v})$ glycerol, and heated for $5 \mathrm{~min}$ at $100^{\circ} \mathrm{C}$. The cell extract was then clarified by centrifugation. The samples $(10 \mu \mathrm{l})$ were electrophoresed for $60 \mathrm{~min}$ at room temperature at $25 \mathrm{~mA}$ per gel in a $12 \%(\mathrm{w} / \mathrm{v})$ resolving gel and a $4.8 \%(w / v)$ stacking gel, and the gels were stained with Coomassie brilliant blue.
Preparation of crude enzyme extracts. E. coli KD301 was grown at $37^{\circ} \mathrm{C}$ in $200 \mathrm{ml}$ Luria-Bertani broth containing $50 \mathrm{mg}$ ampicillin $\mathrm{1}^{-1}$ and gene expression was induced with $0.3 \mathrm{mM}$ IP'TG to $\mathrm{OD}_{550}$ approx. 1.0 (within $2 \mathrm{~h}$ after addition of IPTG). The cells were harvested by centrifugation at $10000 \mathrm{~g}$ for $20 \mathrm{~min}$ at $4{ }^{\circ} \mathrm{C}$, washed twice with ice-cold $50 \mathrm{mM}$ Tris/ $\mathrm{HCl}$ buffer, $\mathrm{pH} \mathrm{7} 0$, containing $10 \mathrm{mM} \mathrm{MgCl}$ and $1 \mathrm{mM}$ EDTA (buffer A), and resuspended in the same buffer $(1 \mathrm{~g}$, wet wt, $\mathrm{ml}^{-1}$ ). The cell suspension was sonicated on ice at $30 \%$ pulsed power eight times for $15 \mathrm{~s}$ with a sonicator (Cell Disrupter model W-225R; Heat Systems). The cell extract was centrifuged at $18000 \mathrm{~g}$ for $30 \mathrm{~min}$ at $4^{\circ} \mathrm{C}$ and the supernatant was passed through a Sephadex G-25 prepacked PD 10 column (Pharmacia LKB Biotechnology) using buffer A containing $20 \%(v / v)$ glycerol as the eluent. Control extracts from the cells of KD300 were prepared in the same manner as the cell extracts from KD301. The protein-containing fraction was collected and glycerol was added to a final concentration of $50 \%(\mathrm{v} / \mathrm{v})$. The resultant crude enzyme extract was stored at $-20^{\circ} \mathrm{C}$ until used.

Enzyme analysis. Glucose-1-phosphate uridylyltransferase activity was determined by measuring the conversion of UTP to UDP-D-glucose by HPLC essentially as described by Marolda \& Valvano (1996). The reaction mixture $(300 \mu \mathrm{l})$ of $50 \mathrm{mM}$ Tris/ $\mathrm{HCl}$ buffer, $\mathrm{pH} 8.0$, containing $12 \mathrm{mM} \mathrm{MgCl}$, $24 \mathrm{mM} \alpha$-D-glucose 1-phosphate, $6 \mathrm{mM} \mathrm{UTP}, 1.8 \mathrm{U}$ inorganic pyrophosphatase (Boehringer) and an appropriate amount of the crude enzyme extract, was incubated at $37^{\circ} \mathrm{C}$. Aliquots $(30 \mu \mathrm{l})$ of the reaction mixture were withdrawn at timed intervals of up to $10 \mathrm{~min}$. The aliquot was immediately mixed with $1.0 \mathrm{ml} 50 \mathrm{mM}$ potassium phosphate buffer, $\mathrm{pH} 3 \cdot 0$, to stop the reaction, and the diluted solutions were stored at $4{ }^{\circ} \mathrm{C}$ until HPLC analysis. Samples $(100 \mu \mathrm{l})$ were analysed by HPLC using a TSKgel QAE-2SW column $(0.46 \times 25 \mathrm{~cm}$; Tosoh). The chromatogram was developed with a linear gradient of $50-600 \mathrm{mM}$ potassium phosphate $(\mathrm{pH} 4 \cdot 0,20 \mathrm{ml}$ ) delivered at a flow rate of $1.0 \mathrm{ml} \mathrm{min}^{-1}$ at $30^{\circ} \mathrm{C}$ and the $A_{254}$ of the effluent was monitored. From the integrated peak areas of the HPLC chromatogram, the molar amount of UDP-glucose formed was calculated. One unit of enzyme activity is defined as the amount of the enzyme catalysing the synthesis of $1 \mu \mathrm{mol}$ UDPD-glucose $\mathrm{min}^{-1}$. To calculate specific activity, the protein concentration in the crude enzyme extract was determined by the method of Bradford (1976) with bovine serum albumin as a standard.

Immunological methods. Lyophilized cell suspensions $(20 \mathrm{~g}$ $1^{-1}$ ) of $S$. mutans strains were suspended in phosphate-buffered 
saline (10 mM, pH 6.8) and autoclaved at $121^{\circ} \mathrm{C}$ for $15 \mathrm{~min}$. After being autoclaved, the suspensions were centrifuged at $10000 \mathrm{~g}$ for $20 \mathrm{~min}$ and the supernatants were collected and used as Rantz-Randall extracts (Rantz \& Randall, 1955). The serotype c antigen was extracted with $5 \%(\mathrm{w} / \mathrm{v})$ trichloroacetic acid from a cell wall preparation of $S$. mutans MT8148 and then the extracted serotype antigen was purified by chromatography on DEAE-Sephadex 25A and Sephacryl S300 columns as described by Linzer et al. (1976). Rabbit antisera against whole cells of strain MT8148 (serotype c) were kindly provided by $\mathrm{T}$. Ooshima, Osaka University Faculty of Dentistry, Japan, and S. Alaluusua, University of Helsinki, Finland. These antisera were absorbed with whole cells of $S$. mutans MT703 (serotype e). Immunodiffusion was performed in $1 \%(\mathrm{w} / \mathrm{v})$ Noble agar in saline (Ouchterlony, 1958).

Analysis of cell-wall sugar components. Bacteria were grown overnight at $37^{\circ} \mathrm{C}$ in $40 \mathrm{ml}$ brain heart infusion broth (Difco), collected by centrifugation and washed three times with distilled water. The cells were resuspended in $1 \mathrm{ml}$ cold distilled water, transferred to a chilled $2 \mathrm{ml}$ microcentrifuge tube containing $0.1 \mathrm{~mm}$ diameter glass beads (GMB-10; Nippon Rikagaku Kikai) and were disrupted with a MiniBead Beater homogenizer (Biospec Products) for $20 \mathrm{~min}$. The glass beads were removed by decantation and the undisrupted cells were separated by centrifugation at $450 \mathrm{~g}$ for $20 \mathrm{~min}$. The crude cell walls were obtained by centrifugation at $8000 \mathrm{~g}$ for $30 \mathrm{~min}$ and washed once with distilled water. The cell walls were treated with RNase $\left(10 \mathrm{mg} \mathrm{l}^{-1}\right)$ and DNase $\left(10 \mathrm{mg} \mathrm{l}^{-1}\right)$ at $37^{\circ} \mathrm{C}$ for $2 \mathrm{~h}$ and with Pronase $\mathrm{E}\left(100 \mathrm{mg} \mathrm{l}^{-1}\right)$ at $37^{\circ} \mathrm{C}$ for $24 \mathrm{~h}$. After being washed twice with distilled water, the cell wall preparations were treated with trypsin $\left(100 \mathrm{mg} \mathrm{l}^{-1}\right)$ at $37^{\circ} \mathrm{C}$ for $2 \mathrm{~h}$. The purified cell walls were collected by centrifugation at $8000 \mathrm{~g}$ for $30 \mathrm{~min}$, washed twice with distilled water and lyophilized.

Component sugars in the purified cell wall preparations were analysed by HPLC with fluorescence labelling. The lyophilized cell wall preparation $(1 \mathrm{mg})$ was resuspended in $0.5 \mathrm{ml}$ distilled water, and $40 \mu \mathrm{l} 5 \mathrm{M}$ trifluoroacetic acid was added to $10 \mu \mathrm{l}$ suspension. The mixture was heated at $100^{\circ} \mathrm{C}$ for $3 \mathrm{~h}$ and dried at $50^{\circ} \mathrm{C}$. Free amino groups were acetylated by adding $50 \mu \mathrm{l}$ of a mixture of pyridine/methanol/water $(3: 6: 2$, by vol.) and $2 \mu \mathrm{l}$ acetic anhydride. The solution was left standing for $30 \mathrm{~min}$ at room temperature. After the hydrolysed solution had been dried at $50^{\circ} \mathrm{C}, 10 \mu \mathrm{l}$ coupling reagent $(670 \mathrm{~g} \mathrm{2}$ aminopyridine $1^{-1}$ in acetic acid) was added. The suspension was heated at $90^{\circ} \mathrm{C}$ for $20 \mathrm{~min}$, the excess reagents were removed by evaporating, and then $10 \mu$ reducing reagent $(60 \mathrm{~g}$ borane-dimethylamine complex $\mathbf{l}^{-1}$ in acetic acid) was added. The mixture was reduced at $90^{\circ} \mathrm{C}$ for $35 \mathrm{~min}$ and dried under a stream of nitrogen gas at $50^{\circ} \mathrm{C}$ for $10 \mathrm{~min}$. The dried sample was dissolved in $1 \mathrm{ml}$ distilled water, and $5 \mu$ of the solution was analysed by HPLC with a PALPAK type A column (Takara Shuzo). D-Glucose, L-rhamnose, N-acetylglucosamine and $\mathrm{N}$-acetylmuramic acid were also coupled with 2aminopyridine as described above and the resultant pyridylamino D-glucose, pyridylamino L-rhamnose, pyridylamino $\mathrm{N}$-acetylglucosamine and pyridylamino $\mathrm{N}$-acetylmuramic acid were used as standards. The buffer used was a mixture of $0.7 \mathrm{M}$ boric acid ( $\mathrm{pH} 9.0$ ) and acetonitrile $(9 \cdot 5: 0.5)$. The flow rate was $0.3 \mathrm{ml} \mathrm{min} \mathrm{m}^{-1}$ and the column was operated at $65^{\circ} \mathrm{C}$. An excitation wavelength of $310 \mathrm{~nm}$ and an emission wavelength of $380 \mathrm{~nm}$ were used to detect the pyridylamino sugars. Pyridylaminated D-fucose $\left(10 \mu \mathrm{l}, 1 \mu \mathrm{mol} \mathrm{l}^{-1}\right)$ was used as a standard for quantification of the pyridylamino sugars. The total hexose content in the purified cell-wall preparation was quantified by the anthrone/sulfuric acid method (Morris, 1948). The hexosamine content in the purified cell-wall preparation was determined by the colorimetric method of Strominger et al. (1959).

Determination of UDP-D-glucose concentration in cells. The intracellular UDP-D-glucose concentrations of strain Xc and its derivatives were determined by using UDP-D-glucose dehydrogenase and NAD. The cells were grown in $45 \mathrm{ml}$ Todd-Hewitt broth to $\mathrm{OD}_{550} 0 \cdot 7$, harvested by centrifugation at $7000 \mathrm{~g}$ for $10 \mathrm{~min}$ at $4{ }^{\circ} \mathrm{C}$ and washed twice with distilled water. The cells were resuspended in $400 \mu \mathrm{l}$ distilled water and transferred to $0.5 \mathrm{ml}$ microcentrifuge tubes containing $0.5 \mathrm{~g}$ $0.1 \mathrm{~mm}$ diameter glass beads. The bacterial cells were disrupted with a Mini-Bead Beater homogenizer for $5 \mathrm{~min}$. The supernatant which was obtained by centrifugation at $20000 \mathrm{~g}$ for $30 \mathrm{~min}$ at $4^{\circ} \mathrm{C}$ was separated into two equal portions. One of the portions was boiled for $90 \mathrm{~s}$, cleared by centrifugation at $20000 \mathrm{~g}$ for $15 \mathrm{~min}$ and used to determine the UDP-D-glucose concentration as described by Keppler \& Decker (1974). The other portion was used for determination of the protein concentration by the method of Bradford (1976).

Evaluation of tolerance of the mutant to environmental stress. Tolerance of $S$. mutans Xc31 toward environmental stresses was evaluated by monitoring growth in Todd-Hewitt broth containing $50 \mathrm{mM}$ sodium acetate buffer at appropriate $\mathrm{pH}$ values or various concentrations $(0-0.9 \mathrm{M})$ of $\mathrm{NaCl}$. Temperature sensitivity was determined from 37 to $45^{\circ} \mathrm{C}$. Strain Xc24 (Tsukioka et al., 1997a), which was totally defective in the serotype antigen due to the insertion of an erythromycin resistance gene into the $r m l B$ gene, was also examined to determine the role of the serotype antigen in environmental stress tolerance of $S$. mutans. In addition to the wild-type strain Xc, strain Xc22 (Tsukioka et al., 1997a), in which the erythromycin resistance gene was inserted into the gene immediately upstream of $r m l A$ and in which serotypespecific polysaccharide antigen was not affected, was used as an erythromycin-resistant control strain. To initiate the growth experiments, overnight cultures of each strain were inoculated into fresh Todd-Hewitt broth and the growth was monitored by measuring $\mathrm{OD}_{550}$. Except for $\mathrm{Xc24}$, the culture was grown at $37^{\circ} \mathrm{C}$ to $\mathrm{OD}_{550} 0.7$ and $150 \mu$ culture broth was then inoculated into $3 \mathrm{ml}$ Todd-Hewitt broth with the indicated modification to evaluate cell viability in conditions of low $\mathrm{pH}$ and high osmotic pressure. When thermotolerance was evaluated, $300 \mu \mathrm{l}$ culture was used as inoculum. The growth was evaluated by measuring $\mathrm{OD}_{550}$. Inocula of $\mathrm{Xc24}$ were taken from cultures grown to $\mathrm{OD}_{550} 0.4$ because $\mathrm{Xc} 24$ grown in the broth exhibited aggregation and about $70 \%$ increase in $\mathrm{OD}_{550}$ was obtained by sonication. When $\mathrm{OD}_{550}$ increase had ceased in the experimental cultures, the culture broth was sonicated at $20 \%$ pulsed power three times for $5 \mathrm{~s}$ with a sonicator (Cell Disrupter model W-225R) and final $\mathrm{OD}_{550}$ values for Xc24 were measured.

\section{RESULTS \\ Cloning and nucleotide sequencing of the S. mutans gluA gene}

Southern blot analysis revealed that the $3.3 \mathrm{~kb} \mathrm{XbaI}$ fragment of the $S$. mutans Xc chromosomal DNA hybridized to probe 1 . An $S$. mutans clone bank constructed with $\mathrm{XbaI}$-digested $S$. mutans Xc chromosomal DNA and pBluescriptII $\mathrm{KS}^{+}$was screened for the gene by colony hybridization. A plasmid designated 


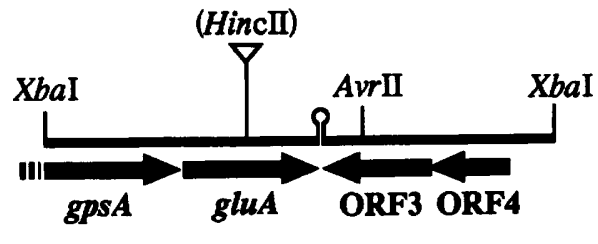

pYT6

pMG1

$1 \mathrm{~kb}$

Fig. 1. Restriction map of the gluA gene of $S$. mutans $X_{C}$ and its flanking regions. Locations of the four ORFs are indicated by the arrows. The pResEmNot insertion site (Hincll site) for insertional inactivation of the gluA gene is indicated by the inverted open triangle. The inverted repeating unit is denoted by an omega loop.

pYT6 containing the target $3.3 \mathrm{~kb} \mathrm{XbaI}$ fragment was obtained (Fig. 1).

Nucleotide sequence analysis of the fragment revealed the presence of four ORFs. Their locations, extents and directions are shown in Fig. 1. The amino acid sequence deduced from the nucleotide sequence of the second ORF demonstrated significant homology to glucose-1phosphate uridylyltransferase encoded by the cps $3 U$ gene (Dillard et al., 1995) (Table 3) and therefore ORF2 was designated gluA (Fig. 1). The first ORF encoded a putative amino acid sequence showing $55.9 \%$ identity with the carboxyl-terminal end of an $\mathrm{NAD}(\mathrm{P}) \mathrm{H}$-dependent dihydroxyacetone phosphate reductase of $B$. subtilis, which is required for phospholipid synthesis (Morbidoni et al., 1995) and was designated gpsA. Two other ORFs, ORF3 and ORF4, on the opposite strand were also identified downstream of the $g l u A$ gene. No proteins homologous to the predicted gene products of these two ORFs were identified in a search of the PIR and SWISS-PROT protein databases.

The region downstream of the gluA gene contained an inverted repeat structure (positions 1764-1783) followed by a poly $(\mathrm{T})$ sequence, which may act as a transcription terminator for the gluA gene. On the opposite strand, this inverted repeat structure was also followed by a poly $(T)$ sequence possibly acting as a transcription terminator for ORF3. The gluA gene was preceded by a putative $5^{\prime}$ GGAG $3^{\prime}$ ribosome-binding site located 8 bp upstream of the initiation codon found at nucleotide position 855 . The predicted translational product of the gluA gene is a protein of 306 amino acids with a molecular mass of $33903 \mathrm{Da}$. The ATG translational initiation codon of the $g l u A$ gene was identified at $1 \mathrm{bp}$ behind the TAA stop codon of the gpsA gene and a putative promoter sequence for the gluA gene was not identified in the upstream region of the gluA gene, suggesting polycistronic transcription of $g p s A$ and $g l u A$.

\section{Expression of the gluA gene in E. coli}

To characterize the product of the $g l u A$ gene, the fragment containing the gene was subcloned into pBluescriptII $\mathrm{KS}^{+}$(Fig. 1). The resultant plasmid (pMG1) was introduced into E. coli strain S $\phi 874-16$. SDS-PAGE followed by Coomassie brilliant blue staining (Fig. 2) demonstrated distinct expression of the $g l u A$ gene in E. coli S $\phi 874-16$ harbouring pMG1 (lane 1) in the presence of IPTG as compared with the same transformant grown in the absence of IPTG (lane 2) and with KD300 (lane 3) as a control strain. The apparent molecular mass estimated by SDS-PAGE was around $41 \mathrm{kDa}$.

\section{Enzyme activity of the gluA gene product}

The $g l u A$ gene product was prepared from KD301 ( $E$. coli $S \phi 874-16$ harbouring pMG1). The activity of glucose-1-phosphate uridylyltransferase was assayed by HPLC. The enzyme preparation from KD301 showed a specific activity of $1.01 \pm 0.04 \mathrm{U}$ (mg protein $)^{-1}$ (mean $\pm \mathrm{sD}, n=3$ ). The activity was significantly higher than that of the cell extract from KD300 used as a control: $0.011 \pm 0.002 \mathrm{U}$ (mg protein $)^{-1}$.

\section{Characterization of the function of the gluA gene in S. mutans}

To analyse the function of the gluA gene in S. mutans, the gene was insertionally inactivated by homologous recombination. The gene was interrupted by pRes-

Table 3. Amino acid sequence identity among uridylyltransferase-related gene products

\begin{tabular}{|c|c|c|c|c|c|c|}
\hline \multirow[t]{2}{*}{ Protein } & \multicolumn{4}{|c|}{ Percentage identity* } & \multirow[t]{2}{*}{ Species } & \multirow[t]{2}{*}{ Reference } \\
\hline & Cps3U & HasC & GalU & GalF & & \\
\hline GluA & $76 \cdot 8$ & $85 \cdot 2$ & $40 \cdot 1$ & $33 \cdot 8$ & S. mutans Xc & This study \\
\hline Cps3U & & $76 \cdot 3$ & $38 \cdot 7$ & $32 \cdot 5$ & S. pneumoniae WU2 & Dillard et al. (1995) \\
\hline HasC & & & $38 \cdot 1$ & $35 \cdot 1$ & S. pyogenes WF51 & Crater et al. (1995) \\
\hline GalU & & & & $53 \cdot 0$ & E. coli $\mathrm{K}-12$ & Weissborn et al. (1994) \\
\hline GalF & & & & & E. coli $\mathrm{K}-12$ & Yao \& Valvano (1994) \\
\hline
\end{tabular}

* Percentage of identical amino acids over length of the protein sequence based on CLUSTAL V alignment. 


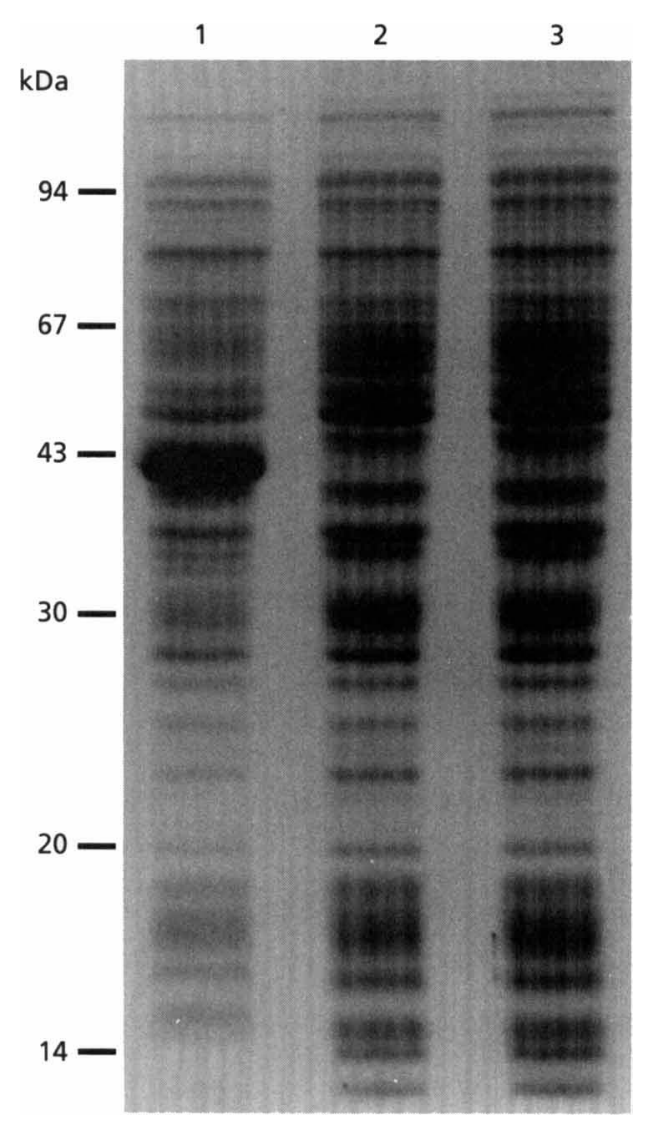

Fig. 2. SDS-PAGE analysis of gluA gene expression in $E$. coli. Lane 1 , cell lysate of $S \phi 874-16$ (pMG1) grown in the presence of $0.3 \mathrm{mM}$ IPTG; lane 2, cell lysate of $S \phi 874-16$ (pMG1) grown in the absence of IPTG; lane 3, cell lysate of S $\phi 874-16$ (pBluescriptll $\mathrm{KS}^{+}$) grown in the presence of $5 \mathrm{mM}$ IPTG. The positions of standard molecular mass markers are indicated.

EmNot (Shiroza \& Kuramitsu, 1993) at the Hincll site and one of the resultant mutants was designated Xc31. The intracellular concentration of UDP-D-glucose in Xc31 grown in Todd-Hewitt broth was lower than $0.1 \mathrm{nmol}$ (mg protein $)^{-1}$, whereas that of UDP-D-glucose in Xc grown in the broth was $11 \pm 3 \mathrm{nmol}$ (mg protein $)^{-1}$ (mean $\pm \mathrm{SD}, n=3$ ). The concentrations of UDP-D-glucose in Xc22 and Xc24 were not significantly different from that in the parental strain Xc. The Rantz-Randall extracts from strains $\mathrm{Xc}$ and Xc31 were analysed by immunodiffusion with serotype antiserum (Fig. 3). Serotype antiserum reacted with the serotype $c$ antigen purified from S. mutans MT8148 and with RantzRandall extract from strain MT8148, but not with Rantz-Randall extracts from MT703 (serotype e) and OMZ175 (serotype $\mathrm{f}$ ), indicating that the serotype antiserum used in the present study does indeed possess serotype $c$ specificity (Fig. 3). The serotype-c-specific antiserum reacted with the extract from strain $\mathrm{X}_{\mathrm{c}}$ but not with that from Xc31 (Fig. 3). The sugar compositions of the cell wall preparations isolated from strain $\mathrm{Xc}$ and the mutant strain were analysed by HPLC (Fig. 4). The ratio of rhamnose to glucose in the cell wall

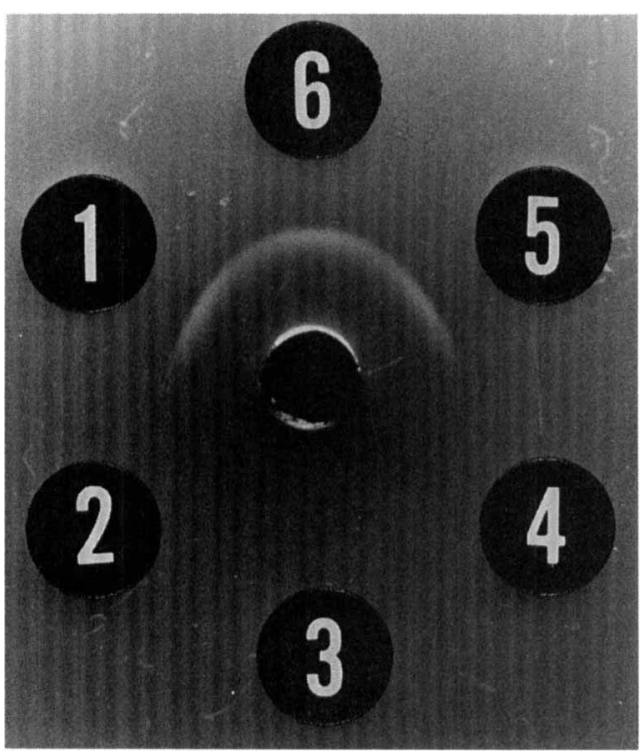

Fig. 3. Immunodiffusion analysis of Rantz-Randall extracts with anti-serotype-c serum. The centre well contains rabbit antiserotype-c serum. The outer wells contain the Rantz-Randall extracts $(20 \mu \mathrm{l})$ from strains Xc (well 1), Xc31 (well 2), MT703 (well 3), OMZ175 (well 4) and MT8148 (well 5). Well 6 contains the purified serotype $c$ antigen $(1 \mu \mathrm{g})$ from strain MT8148.

preparations from Xc was nearly 2 . In contrast, glucose was barely detectable in the cell-wall preparation from the mutant strain Xc31. No significant difference in hexosamine content of the purified cell-wall preparations was observed between $\mathrm{Xc}$ and $\mathrm{Xc31}$ (data not shown).

\section{Environmental stress tolerance of the mutant}

The mutant strain $\mathrm{Xc} 31$ barely grew in medium of $\mathrm{pH}$ below $5 \cdot 6$ and showed apparent deficiency of aciduricity as compared with the control strains Xc22 and Xc when the culture in exponential phase was inoculated (Table 4). Strain Xc24 showed an overall reduction in growth compared with Xc and Xc22 in an acidic medium, but it grew better than Xc31. Xc31 also showed obvious growth inhibition but grew better than Xc24 at temperatures at or above $43^{\circ} \mathrm{C}$, while $\mathrm{Xc}$ and $\mathrm{Xc} 22$ grew relatively well at $44^{\circ} \mathrm{C}$ (Table 5 ). In contrast, $\mathrm{Xc} 31, \mathrm{Xc}$ and Xc22 did not greatly differ from each other in their growth in the presence of various concentrations of $\mathrm{NaCl}(0-0.9 \mathrm{M})$, whereas the growth of Xc24 was drastically inhibited by $\mathrm{NaCl}$ (Table 6).

\section{Southern blot analysis}

Fragments reactive to probe 2 were evident in all of the streptococci tested, as well as in L. casei, Enterococcus faecalis, B. subtilis and C. bifermentans, and a faint band was detected in Stapbylococcus aureus (Fig. 5). Two distinct hybridization bands were detected in Streptococcus pyogenes and S. pneumoniae (Fig. 5, lanes 

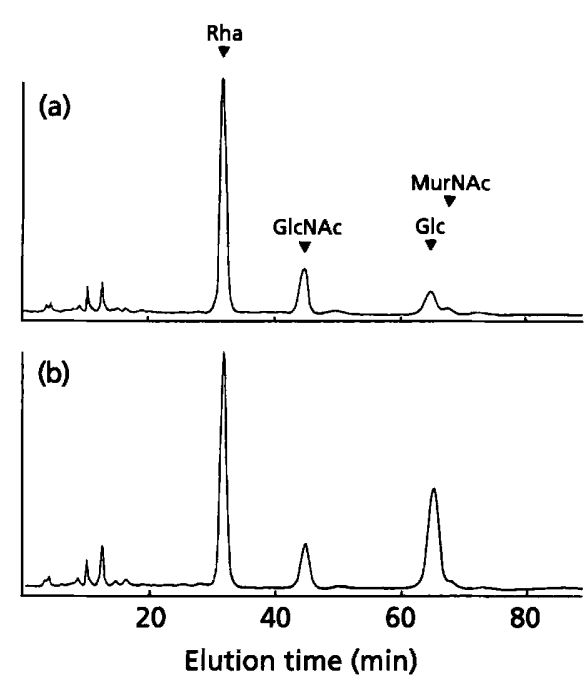

Fig. 4. HPLC pattern of monosaccharides obtained by acid hydrolysis of cell-wall preparations of $S$. mutans strains Xc31 (a) and $X C(b)$. The pyridylamino sugars were analysed with HPLC using a PALPAK type A column. The buffer used was a mixture of $0.7 \mathrm{M}$ boric acid (pH 9.0) and acetonitrile $(9.5: 0.5, \mathrm{v} / \mathrm{v})$, the flow rate was $0.3 \mathrm{ml} \mathrm{min}^{-1}$ and the column was operated at $65^{\circ} \mathrm{C}$. An excitation wavelength of $310 \mathrm{~nm}$ and an emission wavelength of $380 \mathrm{~nm}$ were used to detect the pyridylamino sugars. Arrowheads labelled Rha, GlcNAc, Glc and MurNAc indicate the elution times of pyridylaminated L-rhamnose, pyridylaminated $\mathrm{N}$-acetylglucosamine, pyridylaminated $\mathrm{D}$ glucose and pyridylaminated $\mathrm{N}$-acetylmuramic acid, respectively.

12-14). However, no band for gluA was detected in other Gram-positive bacteria such as Eubacterium limosum, Micrococcus luteus or Mycobacterium smegmatis (Fig. 5), nor in the Gram-negative bacteria Porphyromonas gingivalis, Actinobacillus actino- mycetemcomitans, E. coli, Salmonella typhimurium and Shigella flexneri (data not shown).

\section{DISCUSSION}

In the present study, we cloned the gluA gene of $S$. mutans using the cps3U gene (Dillard et al., 1995) of $S$. pneumoniae as a probe. The amino acid sequence deduced from the nucleotide sequence of the gluA gene has $76.8 \%$ identity with that deduced from the nucleotide sequence of the cps3U gene (Table 3). However, inactivation of $c p s 3 U$ does not affect the phenotype of $S$. pneumoniae (Dillard et al., 1995). Furthermore, the GalF protein of $E$. coli, which has substantial amino acid sequence identity with bacterial glucose-1-phosphate uridylyltransferases such as the GalU protein of E. coli (Table 3), was shown to be non-catalytic but rather to act as a modulator of GalU activity by increasing the formation of UDP-D-glucose (Marolda \& Valvano, 1996). Therefore, it is important to confirm enzymic activity, especially in the case of glucose-1-phosphate uridylyltransferase. We tried to evaluate the enzymic activity of the gluA gene product expressed in E. coli. Because the enzyme encoded by $r m l A$, which was previously referred to as $r f b A$ (Reeves et al., 1996), is known to exhibit not only glucose-1-phosphate thymidylyltransferase activity but also glucose-1-phosphate uridylyltransferase activity in wild-type E. coli (Weissborn et al., 1994), we constructed an E. coli strain in which both the galU and $r m l A$ genes were inactivated to enable evaluation of the enzymic activity of the gluA gene product synthesized in E. coli. Recently, it has been reported that the $r f f H$ gene encodes glucose-1-phosphate thymidylyltransferase (Marolda \& Valvano, 1995). It is possible that the $r m l A$ - and galU-defective strain $S \phi 874$ 16 might retain residual glucose-1-phosphate uridylyltransferase activity. However, the background activity was low enough to evaluate observed increases in

\section{Table 4. Effect of $\mathrm{pH}$ on growth of S. mutans strains}

Cultures were grown in Todd-Hewitt broth containing $50 \mathrm{mM}$ sodium acetate buffer. The indicated $\mathrm{pH}$ value was the starting $\mathrm{pH}$ of each Todd-Hewitt broth after addition of sodium acetate buffer. The Todd-Hewitt broth was prepared three times, and each value (mean $\pm \mathrm{SD}$ ) of the starting $\mathrm{pH}$ was obtained from independent triplicate samples using each preparation. Growth of each strain was determined as the increase of $\mathrm{OD}_{550}$. The values were obtained by subtraction of the $\mathrm{OD}_{550}$ at initiation of the culture from that at stationary phase. Each value represents the mean \pm sD for triplicate cultures from three independent colonies.

\begin{tabular}{|c|c|c|c|c|}
\hline \multirow[t]{2}{*}{ pH } & \multicolumn{4}{|c|}{ Growth (increase in $\mathrm{OD}_{550}$ ) of strain: } \\
\hline & $\begin{array}{c}\mathrm{Xc31} \\
\text { (gluA inactive })\end{array}$ & $\begin{array}{c}\mathrm{Xc24} \\
(r m l B \text { inactive })\end{array}$ & $\begin{array}{c}\mathrm{Xc22} \\
\text { (ORF3 inactive) }\end{array}$ & $\begin{array}{c}\text { Xc } \\
\text { (wild-type) }\end{array}$ \\
\hline $7 \cdot 59 \pm 0.06$ & $1 \cdot 156 \pm 0 \cdot 050$ & $0.842 \pm 0.063$ & $1 \cdot 277 \pm 0 \cdot 024$ & $1 \cdot 283 \pm 0.039$ \\
\hline $5.97 \pm 0.06$ & $0.591 \pm 0.144$ & $0.737 \pm 0.052$ & $1 \cdot 166 \pm 0 \cdot 043$ & $1 \cdot 155 \pm 0.057$ \\
\hline $5 \cdot 75 \pm 0.08$ & $0 \cdot 235 \pm 0 \cdot 113$ & $0 \cdot 678 \pm 0.071$ & $1.086 \pm 0.083$ & $1.098 \pm 0.092$ \\
\hline $5 \cdot 60 \pm 0 \cdot 08$ & $0.129 \pm 0.097$ & $0 \cdot 612 \pm 0 \cdot 080$ & $1.051 \pm 0.088$ & $1.049 \pm 0.076$ \\
\hline $5.41 \pm 0.06$ & $0.035 \pm 0.018$ & $0 \cdot 374 \pm 0 \cdot 118$ & $0 \cdot 878 \pm 0 \cdot 142$ & $0.912 \pm 0 \cdot 104$ \\
\hline $5 \cdot 24 \pm 0 \cdot 07$ & $0 \cdot 014 \pm 0 \cdot 010$ & $0 \cdot 177 \pm 0 \cdot 038$ & $0 \cdot 490 \pm 0 \cdot 215$ & $0.463 \pm 0.191$ \\
\hline
\end{tabular}


Table 5. Effect of temperature on growth of S. mutans strains

Each strain was cultured at the indicated temperature in Todd-Hewitt broth. Growth of each strain was determined as described for Table 4. Each value represents the mean \pm sD for triplicate cultures from three independent colonies.

\begin{tabular}{|lcccc|}
\hline Temp. $\left({ }^{\circ} \mathrm{C}\right)$ & \multicolumn{4}{c|}{ Growth (increase in OD $_{550}$ ) of strain: } \\
\cline { 2 - 5 } & $\mathbf{X c 3 1}$ & $\mathbf{X c 2 4}$ & $\mathbf{X c 2 2}$ & $\mathbf{X c}$ \\
\hline 37 & $1.165 \pm 0.049$ & $1.042 \pm 0.055$ & $1.298 \pm 0.041$ & $1.287 \pm 0.038$ \\
43 & $0.569 \pm 0.083$ & $0.103 \pm 0.028$ & $1.224 \pm 0.033$ & $1.225 \pm 0.057$ \\
44 & $0.117 \pm 0.028$ & $0.014 \pm 0.005$ & $1.040 \pm 0.036$ & $1.056 \pm 0.029$ \\
45 & $0.024 \pm 0.016$ & $0.005 \pm 0.003$ & $0.311 \pm 0.072$ & $0.292 \pm 0.064$ \\
\hline
\end{tabular}

Table 6. Effect of $\mathrm{NaCl}$ concentration on growth of S. mutans strains

Cultures were grown in Todd-Hewitt broth containing the indicated concentration of $\mathrm{NaCl}$. Growth of each strain was determined as described for Table 4. Each value represents the mean $\pm S D$ for triplicate cultures from three independent colonies.

\begin{tabular}{|lcccc|}
\hline \multirow{2}{*}{$\mathrm{NaCl}$ concn $(\mathrm{M})$} & \multicolumn{4}{c|}{ Growth (increase in OD $_{550}$ ) of strain: } \\
\cline { 2 - 5 } & $\mathbf{X c 3 1}$ & $\mathrm{Xc24}$ & $\mathrm{Xc22}$ & $\mathrm{Xc}$ \\
\hline 0 & $\mathbf{1 . 1 7 6 \pm 0 . 0 5 2}$ & $1.086 \pm 0.047$ & $1.310 \pm 0.027$ & $1.319 \pm 0.047$ \\
0.4 & $0.980 \pm 0.074$ & $0.290 \pm 0.158$ & $1.082 \pm 0.033$ & $1.063 \pm 0.055$ \\
0.6 & $0.648 \pm 0.130$ & $0.043 \pm 0.022$ & $0.814 \pm 0.073$ & $0.779 \pm 0.062$ \\
0.7 & $0.285 \pm 0.094$ & $0.026 \pm 0.013$ & $0.478 \pm 0.091$ & $0.492 \pm 0.079$ \\
0.8 & $0.059 \pm 0.026$ & $0.017 \pm 0.017$ & $0.073 \pm 0.032$ & $0.076 \pm 0.034$ \\
0.9 & $0.017 \pm 0.012$ & $0.008 \pm 0.007$ & $0.028 \pm 0.011$ & $0.029 \pm 0.024$ \\
\hline
\end{tabular}

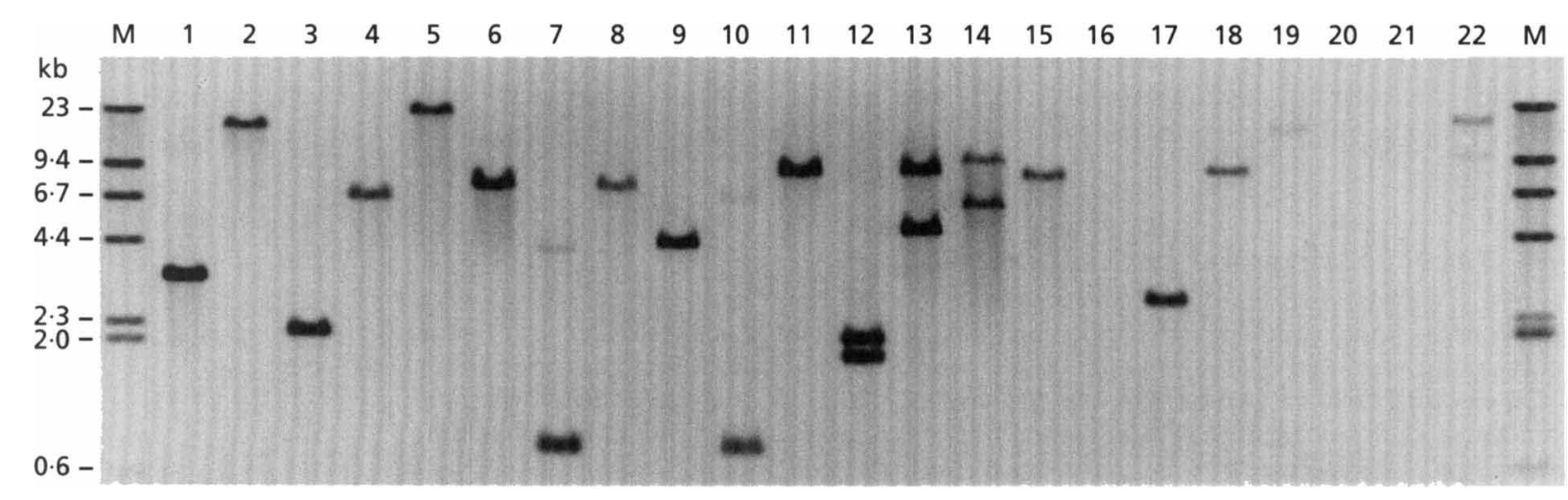

Fig. 5. Southern blot hybridization of chromosomal DNA from various bacterial species using probe 2 (see Methods). Lanes: 1, Streptococcus mutans XC; 2, S. cricetus HS1; 3, S. rattus FA1; 4, S. sobrinus 6715; 5, S. downei MFe28; 6, S. salivarius HT9R; 7, S. milleri NCTC 10703; 8, S. mitior ATCC 12396; 9, S. oralis ATCC 10557; 10, S. gordonii ATCC 10558; 11, S. agalactiae IID1625; 12 and 13, S. pyogenes T29; 14, S. pneumoniae WU2; 15, Enterococcus faecalis SS499; 16, Eubacterium limosum GAI5456; 17, Lactobacillus casei ATCC 393; 18, Bacillus subtilis 168; 19, Staphylococcus aureus IFO12732; 20, Micrococcus luteus GIFU8717; 21, Mycobacterium smegmatis RIMD1332001; 22, Clostridium bifermentans KZ1012. Lanes $M$ contain standard markers with their sizes indicated in kb. DNA was digested with the following enzymes: lane 1, Xbal; lane 12, HindIII; lane 14, Bg/lI; lane 21, BamHI; lanes 13, 16 and 20, Pstl; all other lanes, EcoRI. Hybridization with probe 2 was carried out overnight at $25^{\circ} \mathrm{C}$ in the presence of $50 \%$ formamide.

enzyme activity. The enzyme extract from KD301 expressing the gluA gene exhibited significant glucose-1phosphate uridylyltransferase activity compared with that of KD300, suggesting that gluA encodes the glucose1-phosphate uridylyltransferase of $S$. mutans. Based on SDS-PAGE analysis, the protein product of $g l u A$ has an 
apparent molecular mass of $41 \mathrm{kDa}$. This size is larger than the size of $35.3 \mathrm{kDa}$ predicted from the sequence analysis. The difference could be due to protein secondary structure causing slower than expected migration in the gel. Such a difference in molecular mass has also been noted in glucose-1-phosphate uridylyltransferases of other bacteria, including GalU of $E$. coli (Weissborn et al., 1994) and HasC of S. pyogenes (Crater et al., 1995). The HasC protein is involved in hyaluronic acid synthesis in $S$. pyogenes and the amino acid sequence of the protein has $85.2 \%$ identity with that of the gluA gene product (Table 3).

Serotype-specific polysaccharide antigens of $S$. mutans have been reported to have a poly-L-rhamnose backbone with D-glucose side-chains (Linzer et al., 1986; Pritchard et al., 1986). Insertional inactivation of the gluA gene of $S$. mutans resulted in loss of serotype-c-specific antigenicity of the autoclaved extract (Fig. 3) and intracellular UDP-glucose in the gluA mutant cells (Xc31) was scarcely detected. Furthermore, HPLC analysis of cell wall preparation from Xc31 showed a dramatic decrease in glucose content but not in thamnose content (Fig. 4). These findings suggest that the serotype-cspecific antiserum used in this study might recognize the glucose side-chains of the polysaccharide antigen, and lack of incorporation of glucose into the branches of the rhamnose backbone might lead to loss of serotype-cspecific antigenicity of Xc31. Moreover, the inactivation of the gluA gene apparently has no effect on the synthesis of the core rhamnose moiety. It may be concluded that UDP-D-glucose is an immediate precursor for glucose side-chain formation of the serotype-c-specific antigen of $S$. mutans. Recently, the $S$. mutans galactose operon comprising genes for galactose metabolism (galactokinase, galactose-1-phosphate uridylyltransferase and UDP-glucose-4-epimerase) was cloned and characterized (Ajdic et al., 1996). UDP-D-glucose is theoretically synthesized from galactose via this pathway. However, the extract from Xc31 grown in the presence of $0.5 \%(\mathrm{w} / \mathrm{v})$ galactose did not react with the antiserum (data not shown), suggesting that the galactose metabolism pathway does not complement the gluA gene function in Xc31.

Southern blot analysis showed that two gluA-specific probe-reactive fragments were positioned at $6.2 \mathrm{~kb}$ and $10 \mathrm{~kb}$ in the BglII-digested chromosomal DNA of $S$. pneumoniae WU2 (Fig. 5, lane 14). This indicates that two copies of the homologous gene exist in the chromosomal DNA of $S$. pneumoniae WU2, since there is no restriction site for $B g l I I$ within the $c p s 3 U$ gene (Dillard et al., 1995). Two probe-reactive fragments were also identified in $S$. pyogenes chromosomal DNA (Fig. 5, lanes 12 and 13). The BLAST program was used to search the $S$. pyogenes genome sequencing database for homology to the $g l u A$ gene. The database can be found at the WorldWide Web site of the University of Oklahoma's Advanced Center for Genome Technology (URL: http://dna1.chem.uoknor.edu/strep.html) and the sequence data were registered in the various contigs in 'random' order. Two genes homologous to gluA were found in different contigs. The arrangement of the flanking genes of the homologous gene in one contig was similar to that of the $g l u A$ gene, whereas the arrangement of the flanking genes found in the other contig resembled that of the flanking genes of the has $C$ and cps3U genes (Crater et al., 1995; Dillard et al., 1995). In addition to the major band, a weakly reactive fragment was observed in S. milleri (Fig. 5, lane 7), S. gordonii (Fig. 5, lane 10) and C. bifermentans (Fig. 5, lane 22). These minor bands might be derived from an occurrence of the restriction site within the gluA homologue gene in these bacteria. Streptococcus species other than $S$. pneumoniae and S. pyogenes examined in this study are likely to have a single copy of the gene encoding glucose1-phosphate uridylyltransferase based on the results of Southern blot analysis (Fig. 5).

The observation that the lack of UDP-D-glucose in $E$. coli results in an increase in the basal level of the expression of the $\sigma^{\mathrm{s}}$ gene $(r p o S)$ and $\sigma^{\mathrm{s}}$-dependent genes induced by osmotic pressure or during entry into stationary phase suggests that UDP-D-glucose serves as an intracellular signalling molecule controlling expression of the genes required for osmotolerance and thermotolerance in stationary phase (Böhringer et al., 1995; Giæver et al., 1988; Hengge-Aronis et al., 1991). In earlier work, we reported the isolation of a mutant defective in aciduricity, GS5Tn1, in which a gene homologous to the E. coli dgk (diacylglycerol kinase) gene was partially inactivated (Yamashita et al., 1993). This mutant grew poorly in an acidic environment and was sensitive to high osmolarity and elevated temperatures, leading to speculation that the $g l u A$ gene product, glucose-1-phosphate uridylyltransferase, may also be involved in acid tolerance of $S$. mutans. Interestingly, we found that strain $\mathrm{Xc} 31$, a $\operatorname{glu} A$ null mutant, as well as GS5Tn1, showed drastically reduced aciduricity (Table 4). Aciduricity is known to be one of the most important virulence factors of the organism. In this regard, it is possible that the inability of the $g l u A$ mutant to synthesize the serotype-c-specific polysaccharide is directly responsible for its reduced cell viability in an acidic environment. If the serotype-cspecific polysaccharide is really required for the maintenance of aciduricity, then a mutant that is totally unable to synthesize serotype-c-specific polysaccharide should exhibit the same phenotype as the gluA mutant. However, Xc24, which is a mutant defective in synthesis of serotype-c-specific polysaccharide (Tsukioka et al., 1997a) but has the same levels of intracellular UDP-Dglucose as the wild-type $\mathrm{Xc}$, grew better than $\mathrm{Xc} 31$ in an acidic environment (Table 4), whereas Xc24 scarcely grew at elevated temperature and high osmolarity (Tables 5 and 6), suggesting that UDP-D-glucose synthesis may be required for the maintenance of aciduricity of $S$. mutans. It is also clear that $\mathrm{Xc} 31$ has a reduced cell viability at elevated temperatures, but this reduction was not as pronounced as that of Xc24. At the present stage, we do not have any data to confirm whether UDPD-glucose or serotype-specific antigen is required for cell viability of $S$. mutans at elevated temperature. Growth 
of Xc31 was slightly inhibited even in the absence of $\mathrm{NaCl}$ compared with that of $\mathrm{Xc}$ and $\mathrm{Xc22}$. Inhibition of the growth of Xc31 at high osmolarity was probably due to a comprehensive growth defect, not a defect in osmotic tolerance. Indeed, $\mathrm{Xc} 31$ grew well in the presence of $0.6 \mathrm{M} \mathrm{NaCl}$, despite the fact that Xc24 scarcely grew at that concentration of $\mathrm{NaCl}$, suggesting that osmotolerance of $S$. mutans is not drastically affected by the null mutation of the gluA gene.

In the present study, we evaluated stress tolerance of $S$. mutans growing in the exponential phase and not the stationary phase. Two acid-tolerance responses induced at low $\mathrm{pH}$ were recognized in Salmonella typhimurium: an exponential-phase acid-tolerance response and a stationary-phase acid-tolerance response (Lee et al., 1994). Although induction of these two responses is $\sigma^{\mathrm{s}}$ independent, $\sigma^{\mathrm{s}}$ is required for a sustained induction of the exponential-phase acid-tolerance response (Lee $e t$ al., 1995). Considering that UDP-glucose is a potential intracellular signal molecule in the control of expression of the $r p o S$ gene (Böhringer et al., 1995), it is possible that growth inhibition of Xc31 under acidic conditions may relate to unusual expression of the $r p o S$ homologue in Xc31 cells. Meanwhile, UDP-D-glucose is thought to be a precursor of other cellular components such as glycophospholipids, which are important membrane constituents, and lipoteichoic acid anchors. It is possible that defects in such components might lessen the tolerance of $S$. mutans to conditions of acidity and elevated temperature. However, little information is currently available regarding regulation of the $r p o S$ homologue and UDP-D-glucose metabolism in $S$. mutans. In addition, the mechanism of acid tolerance of $S$. mutans is at present ill-defined. Further studies are required to elucidate the details of the unique biological function of UDP-D-glucose synthesis in this organism.

\section{ACKNOWLEDGEMENTS}

We thank J. Yother for providing pJD366, A. C. Weissborn for providing E. coli JC7623-16, and T. Miki for providing P1vir phage. We are grateful to K. Nakayama for helpful advice. We acknowledge the Streptococcal Genome Sequencing Project, and Bruce Roe, Sandy Clifton, Mike McShan and Joseph Ferretti. This work was supported in part by Grants-in-Aid for Developmental Scientific Research (A) 07557134 (T.K.) and (B) 09470474 (Y.Y.) from the Ministry of Education, Science, Sports and Culture of Japan, the Takeda Science Foundation (Y.Y.) and the Uehara Memorial Foundation (T.K.).

\section{REFERENCES}

Ajdic, D., Sutcliffe, I. C., Russell, R. R. B. \& Ferretti, J. J. (1996). Organization and nucleotide sequence of the Streptococcus mutans galactose operon. Gene 180, 137-144.

Bohringer, J., Fischer, D.، Mosler, G. \& Hengge-Aronis, R. (1995). UDP-glucose is a potential intracellular signal molecule in the control of expression of $\sigma^{\mathrm{s}}$ and $\sigma^{\mathrm{s}}$ dependent genes in Escherichia coli. J Bacteriol 177, 413-422.

Bradford, M. M. (1976). A rapid and sensitive method for the quantitation of microgram quantities of protein utilizing the principle of protein-dye binding. Anal Biochem 72, 248-254.
Bratthall, D. (1970). Demonstration of five serological groups of streptococcal strains resembling Streptococcus mutans. Odontol Revy 21, 143-152.

Crater, D. L., Dougherty, B. A. \& van de Rijn, I. (1995). Molecular characterization of has $C$ from an operon required for hyaluronic acid synthesis in group A streptococci. Demonstration of UDPglucose pyrophosphorylase activity. $J$ Biol Chem 270, 2867628680.

Dillard, J. P. \& Yother, J. (1994). Genetic and molecular characterization of capsular polysaccharide biosynthesis in Streptococcus pneumoniae type 3. Mol Microbiol 12, 959-972.

Dillard, J. P., Vandersea, M. W. \& Yother, J. (1995). Characterization of the cassette containing genes for type 3 capsular polysaccharide biosynthesis in Streptococcus pneumoniae. J Exp Med 181, 973-983.

Giæver, H. M., Styrvold, O. B., Kaasen, I. \& Strøm, A. R. (1988). Biochemical and genetic characterization of osmoregulatory trehalose synthesis in Escherichia coli. J Bacteriol 170, 2841-2849.

Ginsburg, V. (1964). Sugar nucleotides and the synthesis of carbohydrates. Adv Enzymol 26, 35-88.

Hamada, S. \& Slade, H. D. (1976). Purification and immunochemical characterization of type $e$ polysaccharide antigen of Streptococcus mutans. Infect Immun 14, 68-76.

Hengge-Aronis, R., Klein, W., Lange, R., Rimmele, M. \& Boos, W. (1991). Trehalose synthesis genes are controlled by the putative sigma factor encoded by rpoS and are involved in stationaryphase thermotolerance in Escherichia coli. J Bacteriol 173, 7918-7924.

Higgins, D. G., Bleasby, A. J. \& Fuchs, R. (1992). CluSTAL v: improved software for multiple sequence alignment. Comput Appl Biosci 8, 189-191.

Imai, T., Ohta, K., Kigawa, H., Kanoh, H., Taniguchi, T. \& Tobari, J. (1994). Preparation of high-molecular-weight DNA: application to mycobacterial cells. Anal Biochem 222, 479-482.

Jiang, X.-M., Neal, B., Santiago, F., Lee, S. J., Romana, L. K. \& Reeves, P. R. (1991). Structure and sequence of the $r f b$ ( $O$ antigen) gene cluster of Salmonella serovar typhimurium (strain LT2). Mol Microbiol 5, 695-713.

Keppler, D. \& Decker, K. (1974). Uridine-5'-diphosphoglucose. In Methods of Enzymatic Analysis, vol. 4, pp. 2225-2228. Edited by H. U. Bergmeyer. New York: Academic Press.

Koga, T., Asakawa, H., Okahashi, N. \& Takahashi, I. (1989). Effect of subculturing on expression of a cell-surface protein antigen by Streptococcus mutans. J Gen Microbiol 135, 3199-3207.

Laemmli, U. K. (1970). Cleavage of structural proteins during the assembly of the head of bacteriophage T4. Nature 227, 680-685.

Lee, I. S., Slonczewski, J. L. \& Foster, J.W. (1994). A low-pH inducible, stationary-phase acid tolerance response in Salmonella typhimurium. J Bacteriol 176, 1422-1426.

Lee, I. S., Lin, J., Hall, H. K., Bearson, B. \& Foster, J. W. (1995). The stationary-phase sigma factor $\sigma^{\mathrm{s}}(\mathrm{RpoS})$ is required for a sustained acid tolerance response in virulent Salmonella typhimurium. Mol Microbiol 17, 155-167.

Linzer, R., Gill, K. \& Slade, H. D. (1976). Chemical composition of Streptococcus mutans type $c$ antigen: comparison to type $a, b$, and $d$ antigens. $J$ Dent Res Special Issue A 55, A109-A115.

Linzer, R., Reddy, M. S. \& Levine, M. J. (1986). Immunochemical aspects of serotype carbohydrate antigens of Streptococcus mutans. In Molecular Microbiology and Immunobiology of Streptococcus mutans, pp. 29-38. Edited by S. Hamada, S. M. Michalek, H. Kiyono, L. Menaker \& J. R. McGhee. Amsterdam: Elsevier. 
Lipman, D. J. \& Pearson, W. R. (1985). Rapid and sensitive protein similarity searches. Science 227, 1435-1441.

Loesche, W. J. (1986). Role of Streptococcus mutans in human dental decay. Microbiol Rev 50, 353-380.

Markovitz, A. (1977). Genetics and regulation of bacterial capsular polysaccharide biosynthesis and radiation sensitivity. In Surface Carbohydrates of the Prokaryotic Cell, pp. 415-462. Edited by I. Sutherland. New York: Academic Press.

Marolda, C. L. \& Valvano, M. A. (1995). Genetic analysis of the dTDP-rhamnose biosynthesis region of the Escherichia coli VW187 (O7:K1) rfb gene cluster: identification of functional homologs of $r f b B$ and $r f b A$ in the $r f f$ cluster and correct location of the rffE gene. $J$ Bacteriol 177, 5539-5546.

Marolda, C. L. \& Valvano, M. A. (1996). The GalF protein of Escherichia coli is not a UDP-glucose pyrophosphorylase but interacts with the GalU protein possibly to regulate cellular levels of UDP-glucose. Mol Microbiol 22, 827-840.

Martin, V., Kleschyov, A. L., Klein, J.-P. \& Beretz, A. (1997). Induction of nitric oxide production by polysides from the cell walls of Streptococcus mutans OMZ 175, a Gram-positive bacterium, in the rat aorta. Infect Immun 65, 2074-2079.

Miller, J. H. (1992). P1 transduction. In A Short Course in Bacterial Genetics, pp. 263-278. Cold Spring Harbor, NY: Cold Spring Harbor Laboratory.

Morbidoni, H. R., de Mendoza, D. \& Cronan, J. E., Jr (1995). Synthesis of $s n$-glycerol 3-phosphate, a key precursor of membrane lipids, in Bacillus subtilis. J Bacteriol 177, 5899-5905.

Morris, D. L. (1948). Quantitative determination of carbohydrates with Dreywood's anthrone reagent. Science 107, 254-255.

Ohta, H., Kato, H., Okahashi, N., Takahashi, I., Hamada, S. \& Koga, T. (1989). Characterization of a cell-surface protein antigen of hydrophilic Streptococcus mutans strain GS-5. J Gen Microbiol 135, 981-988.

Ouchterlony, ö. (1958). Diffusion-in-gel methods for immunological analysis. Prog Allergy 5, 1-78.

Perry, D., Wondrack, L. M. \& Kuramitsu, H. K. (1983). Genetic transformation of putative cariogenic properties in Streptococcus mutans. Infect Immun 41, 722-727.

Pritchard, D. G., Gregory, R. L., Michalek, S. M. \& McGhee, J. R. (1986). Biochemical aspects of serotype carbohydrate antigens of Streptococcus mutans. In Molecular Microbiology and Immunobiology of Streptococcus mutans, pp. 39-49. Edited by S. Hamada, S. M. Michalek, H. Kiyono, L. Menaker \& J. R. McGhee. Amsterdam: Elsevier.

Rantz, L. A. \& Randall, E. (1955). Use of autoclaved extracts of hemolytic streptococci for serological grouping. Stanford Med Bull 13, 290-291.

Reeves, P., Hobbs, M., Valvano, M. A. \& eight other authors (1996). Bacterial polysaccharide synthesis and gene nomenclature. Trends Microbiol 4, 495-503.
Sambrook, J., Fritsch, E. F. \& Maniatis, T. (1989). Molecular Cloning: a Laboratory Manual, 2nd edn. Cold Spring Harbor, NY : Cold Spring Harbor Laboratory.

Schnaitman, C. A. \& Klena, J. D. (1993). Genetics of lipopolysaccharide biosynthesis in enteric bacteria. Microbiol Rev 57, $655-682$.

Shiroza, T. \& Kuramitsu, H. K. (1993). Construction of a model secretion system for oral streptococci. Infect Immun 61, 37453755.

Soell, M., Lett, E., Holveck, F., Schöller, M., Wachsmann, D. \& Klein, J.-P. (1995). Activation of human monocytes by streptococcal rhamnose glucose polymers is mediated by CD14 antigen, and mannan binding protein inhibits TNF- $\alpha$ release. $J$ Immunol $154,851-860$.

Strominger, J. L., Park, J. T. \& Thompson, R. E. (1959). Composition of the cell wall of Staphylococcus aureus: its relation to the mechanism of action of penicillin. J Biol Chem 234, 3263-3268.

Sundararajan, T. A., Rapin, A. M. C. \& Kalckar, H. M. (1962). Biochemical observations on E. coli mutants defective in uridine diphosphoglucose. Proc Natl Acad Sci USA 48, 2187-2193.

Tsukioka, Y., Yamashita, Y., Oho, T., Nakano, Y. \& Koga, T. (1997a). Biological function of the dTDP-rhamnose synthesis pathway in Streptococcus mutans. J Bacteriol 179, 1126-1134.

Tsukioka, Y., Yamashita, Y., Nakano, Y., Oho, T. \& Koga, T. (1997b). Identification of a fourth gene involved in dTDPrhamnose synthesis in Streptococcus mutans. J Bacteriol 179, 4411-4414.

Weissborn, A. C., Liu, Q., Rumley, M. K. \& Kennedy, E. P. (1994). UTP : $\alpha$-D-glucose-1-phosphate uridylyltransferase of Escherichia coli: isolation and DNA sequence of the galU gene and purification of the enzyme. J Bacteriol 176, 2611-2618.

Wetherell, J. R., Jr \& Bleiweis, A. S. (1975). Antigens of Streptococcus mutans: characterization of a polysaccharide antigen from walls of strain GS-5. Infect Immun 12, 1341-1348.

Yamashita, Y., Takehara, T. \& Kuramitsu, H. K. (1993). Molecular characterization of a Streptococcus mutans mutant altered in environmental stress responses. J Bacteriol 175, 6220-6228.

Yanisch-Perron, C., Vieira, J. \& Messing, J. (1985). Improved M13 phage cloning vectors and host strains: nucleotide sequences of the M13mp18 and pUC19 vectors. Gene 33, 103-119.

Yao, Z. \& Valvano, M. A. (1994). Genetic analysis of the O-specific lipopolysaccharide biosynthesis region $(r f b)$ of Escherichia coli $\mathrm{K}$ 12 W3110: identification of genes that confer group 6 specificity to Shigella flexneri serotypes $Y$ and 4a. J Bacteriol 176, 4133-4143.

Received 12 November 1997; revised 12 January 1998; accepted 14 January 1998. 